\title{
Популяційна щільність Convallaria majalis L. y різних фітоценозах Шосткинського геоботанічного району Сумської області (Україна)
}

\section{Лариса Пеньковська}

Сумський національний аграрний університет, Суми, Україна

Адреса для листування: e-mail: lara_penkovskaya@ukr.net

Отримано: 20.04.20; прийнято до друку: 20.06.20; опубліковано: 02.09.20

Резюме. У статті наведено характеристику популяційної щільністі рослин Convallaria majalis у різних фітоценозах Шосткинського геоботанічного району. Угруповання, у яких репрезентовано досліджувані популяції C. majalis, відрізняються між собою за домінантами ярусу деревостану. У двох із них (Pinetum (sylvestris) sorboso (aucuparii)-elytrigiosum (repentis), Pinetum (sylvestris) coryloso (avellanae)-urticosum (dioicae)) домінантом є Pinus sylvestris L., у трьох (Quercetum (roboris) coryloso (avellanae)-fragariosum (vescae), Quercetum (roboris) coryloso (avellanae)-poosum (nemoralis), Quercetum (roboris) poosum (nemoralis))-Quercus robur L., в одній (Querceto (roboris)-Aceretum (platanoiditis) elytrigietosum (repentis))-Acer platanoides L. при співдомінуванні Q. robur, та ще у двох Tilia cordata Mill. при співдомінуванні Quercus robur.

У досліджуваних популяцій $C$. majalis значення популяційної щільності здебільшого варіюють від 20,4 до 45,5 рослин/м². Однак найбільші показники щільності виявили в угрупованні Querceto (roboris)-Tilieto (cordatae) convallariosum (majalis) - iі величини відповідно досягають 45,5 $\pm 5,13$ рослин/м². В угрупованні Quercetum (roboris) coryloso (avellanae)-fragariosum (vescae) значення цієї характеристики, навпаки, знижені до $20,4 \pm 1,50$ рослин/ $\mathrm{M}^{2}$.

У розподілі значень популяційної щільності виявлено низку закономірностей. Популяції C. majalis, що сформувалися під наметом шпилькових лісів, здебільшого мають менші величини популяційної щільності, ніж ті, що зростають в широколистяних лісах. Чітко виражене збільшення величин популяційної щільності проявляється в ряду звичайнососнові $\rightarrow$ звичайнодубово-дрібнолистянолипові ліси. Відповідно, був проведений аналіз зміни величин популяційної щільності C. majalis на тлі зростання їх популяцій у різних лісорослинних умовах: звичайнососнових лісів (формація Pineta sylvestris, субформація Pineeta sylvestris); 2 - звичайнодубових лісів (формація Querceta roboris, субформація Querceeta roboris); 3 - звичайнодубово-гостролистокленових лісів (формація Acereta platanoiditis, субформація Querceto (roboris)-Acereta platanoiditis); 4 - звичайнодубоводрібнолистянолипових лісів (формація Tilieta cordatae, субформація Querceto (roboris)-Tilieta cordatae).

Ключові слова: популяційна щільність, Convallaria majalis, формація, субформація.

\section{Population Density of Convallaria majalis in Different Phytocenoses of Shostka Geobotanical District of Sumy Region (Ukraine)}

\section{Larysa Penkovska}

Sumy National Agrarian University, Sumy, Ukraine

Address for correspondence: e-mail: lara_penkovskaya@ukr.net

Abstract. The paper contains the characteristics of the population density of Convallaria majalis plants in different phytocenoses of Shostka geobotanical district. The groups in which the populations of C. majalis are represented are different by the dominants of the forest tier. Two of them (Pinetum (sylvestris) sorboso 
(aucuparii)-elytrigiosum (repentis), Pinetum (sylvestris) coryloso (avellanae)-urticosum (dioicae)) are dominated by Pinus sylvestris L., in three (Quercetum (roborisvel aorylory aory))-Fragariosum (vescae), Quercetum (roboris) coryloso (avellanae)-poosum (nemoralis), Quercetum (roboris) poosum (nemoralis)) Quercus robur L., in one (Querceto (roboris)-Aceretum (platanoidos) elytrigietum (platanoidos)) repentis)) Acer platanoides L. when dominated by Quercus robur and two more Tilia cordata Mill. when dominated by Quercus robur.

In the studied populations of C. majalis, the population density values generally range from 20,4 to 45,5 plants/m2. But, the highest density values were found in the Querceto (roboris)-Tilieto (cordatae) convallariosum (majalis) group, respectively, reaching $45.5+5.13$ plants $/ \mathrm{m} 2$. In the Quercetum (roboris) coryloso (avellanae)-fragariosum (vescae) group, the values of this characteristic are, in contrast, reduced to 20.4+1.50 plants $/ \mathrm{m} 2$.

Some regularities have been identified in the distribution of population density values. Populations of C. majalis, formed under the pinnacle forest, tend to have smaller population densities than those growing in deciduous forests. An expressed increase in population increase in population density is manifested in many common pine-deciduous forests. Accordingly, an analysis of the change in population density of C. majalis was conducted against the background of the growth of their populations in different forest plant conditions: common pine forests: (formation Pineta sylvestris, subformations Pineeta sylvestris); 2- oak forests (formation - Querceta roboris, subformation Querceeta roboris); 3 - common oak-maple forest (formation - Acereta platanoiditis, subformation Querceto (roboris) - Acereta platanoiditis); 4 - oak-linden forests (formation - Tilieta cordatae, subformation Querceto (roboris) - Tilieta cordatae).

Keywords: population density, Convallaria majalis, formation, subformation.

\section{ВСТУП}

На сучасному етапі у світі активно проводяться наукові дослідження, спрямовані на вивчення лікарських рослин (видового складу, поширення, запасів, різних аспектів господарського використання), що зростають у тому чи іншому регіоні $[1,2,3]$. Об'єктом таких досліджень є як Українське Полісся $[4,5]$, так і Лівобережне Полісся зокрема. Матеріали, представлені у наявних наукових працях, засвідчують, що Українське Полісся $\epsilon$ унікальним осередком фіторізноманіття та територією, багатою на цінні лікарські рослини. Окрім того, вони вказують на доцільність поглибленого вивчення стану лікарських рослин у межах окремих регіональних одиниць, до числа яких, наприклад, належить Шосткинський геоботанічний район $[6,7,8]$.

Наявні наукові дані доводять, що до числа видів, які мають значне поширення та $\epsilon$ перспективними в ресурсному аспекті, у цьому регіоні, зокрема, належить C. majalis $[9,10]$. Лікарські засоби, отримані на основі сировини C. majalis, здавна застосовують при хворобах серця, головного болю, паралічу, як заспокійливий, сечогінний засіб при безсонні [11].

Закономірним наслідком того, що рослини C. majalis виступають важливими складовими природних комплексів та об'єктами тривалого господарського використання, а разом 3 тим різнопланових ботанічних, хімічних i фармакологічних досліджень, є досить значний обсяг накопиченої інформації про особливості їхньої морфологічної та анатомічної організації, про таксономію, розмноження, поширення, хімічний склад, особливості Ta вимоги щодо користування ресурсами.

На сьогодні в науковій літературі накопичений значний обсяг інформації про поширення й стан популяцій $C$. majalis [12] та iii ресурсний потенціал в окремих регіонах досліджень, хімічний склад i лікарські властивості органів [13]. Біологічні особливості та поширення C. majalis досліджували О. М. Переходько [14], .В.Кацовець [15], ботанічна характеристика й особливості розмноження розглянуто в роботах B. М. Мінарченко [16]. Однак питання дослідження щільності популяцій цього виду та залежності їх від умов місцезростань залишається майже не дослідженим, зокрема й в умовах Шосткинського геоботанічного району Сумської області.

Мета статті - оцінити популяційну щільність C. majalis в різних фітоценозах Шосткинського геоботанічного району Сумської області.

Завдання: оцінити величини популяційної щільності C.majalis у різних лісорослинних умовах; проаналізувати характер зміни цієї характеристики залежно від умов місцезростань; виявити популяції, що $\epsilon$ перспективними осередками заготівлі лікарської сировини цього виду.

\section{МАТЕРІАЛИ ТА МЕТОДИ ДОСЛІДЖЕНЬ}

Об’єктом вивчення є C.majalis, який належить до роду Convallaria, родини Asparagaceae Juss. Відносно ареалу поширення C. majalis - типова лісова рослина, що тра- 
пляється в широколистяних, змішаних, березових, осикових, рідше в соснових лісах. Дослідження проводилися в II-III декаді травня.

3 метою встановлення величин популяційної щільності й онтогенетичної структури популяцій у межах популяційного поля кожної популяції за випадковою системою розташовували 30-50 облікових ділянок площею $0,25 \mathrm{~m}^{2}$. На кожній iз них підраховували загальну кількість екземплярів досліджуваної рослини, а також кількість екземплярів різних онтогенетичних станів. У якості облікових одиниць C. majalis виступали рамети. Статистичне опрацювання отриманих результатів супроводжувалося використанням точкового оцінювання, кореляційного й регресійного аналізу. Виявлення закономірностей реагування величин популяційної щільності на вплив еколого-ценотичних чинників здійснювалося 3 урахуванням загальноприйнятих вимог градієнтного аналізу.

Загалом дослідженнями було охоплено ценопопуляції із восьми угруповань C. majalis, що є типовими для регіону досліджень.

Угруповання, в яких репрезентовано досліджувані популяції C. Majalis, відрізняються між собою за домінантами ярусу деревостану. У двох із них (Pinetum (sylvestris) sorboso (aucuparii)-elytrigiosum (repentis), Pinetum (sylvestris) coryloso (avellanae)urticosum (dioicae)) домінантом є Pinus sylvestris L., у трьох (Quercetum (roboris) coryloso (avellanae)-fragariosum (vescae), Quercetum (roboris) coryloso (avellanae)-poosum (nemoralis), Quercetum (roboris) poosum
(nemoralis))-Quercus robur L., в одній (Querceto (roboris)-Aceretum (platanoiditis) elytrigietosum (repentis))-Acer platanoides L. при співдомінуванні $Q$. robur, та ще у двох Tilia cordata Mill. при співдомінуванні $Q$. robur.

\section{РЕЗУЛЬТАТИ ТА ОБГОВОРЕННЯ}

У досліджуваних популяцій C.majalis значення популяційної щільності здебільшого варіюють від 20,4 до 45,5 рослин/м² (табл. 1). Однак найбільші показники щільності виявили в угрупованні Querceto (roboris)-Tilieto (cordatae) convallariosum (majalis), iii величини

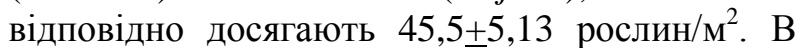
угрупованні Quercetum (roboris) coryloso (avellanae)-fragariosum (vescae) значення цієї характеристики, навпаки, знижені до 20,4+1,50 рослин/м². Узагальнена інформація про показники популяційної щільності представлена в таблиці 1.

У розподілі значень популяційної щільності виявлено низку закономірностей. Популяції C. majalis, що сформувалися під наметом шпилькових лісів, здебільшого мають менші величини популяційної щільності, ніж ті, що зростають в широколистяних лісах. Чітко виражене збільшення величин популяційної щільності проявляється в ряду звичайнососнові $\rightarrow$ звичайнодубово-дрібнолистянолипові ліси (рис. 1).

На величинах популяційної щільності C. majalis негативним чином відбивається i збільшення загальної зімкнутості верхніх ярусів лісу (рис. 2).

Таблиия 1

Популяційна щільність Convallaria majalis в різних фітоценозах

\begin{tabular}{|c|c|c|}
\hline \multirow{2}{*}{$\begin{array}{c}\text { № } \\
\text { популяції }\end{array}$} & Угруповання & $\begin{array}{c}\text { Популяційна } \\
\text { щільність, } \\
\text { рослин/м }{ }^{2}\end{array}$ \\
\hline 1 & Pinetum (sylvestris) sorboso (aucuparii)-elytrigiosum (repentis) & $23,1 \pm 1,64$ \\
\hline 2 & Pinetum (sylvestris) coryloso (avellanae)-urticosum (dioicae) & $25,8 \pm 2,27$ \\
\hline 3 & Quercetum (roboris) coryloso (avellanae)-fragariosum (vescae) & $20,4 \pm 1,50$ \\
\hline 4 & Quercetum (roboris) coryloso (avellanae)-poosum (nemoralis) & $21,0 \pm 1,78$ \\
\hline 5 & Querceto (roboris) poosum (nemoralis) & $26,8 \pm 3,18$ \\
\hline 6 & Querceto (roboris)-Aceretum (platanoiditis) elytrigietosum (repentis) & $25,0 \pm 1,74$ \\
\hline 7 & Querceto (roboris)-Tilieto (cordatae) convallariosum (majalis) & $45,5 \pm 5,13$ \\
\hline 8 & Querceto (roboris)-Tilietum (cordatae) urticosum (dioicae) & $27,4 \pm 1,91$ \\
\hline
\end{tabular}


Популяиійна щиільність Convallaria majalis L. у різних фітоценозах Шосткинського геоботанічного району Сумської області (Украӥна)

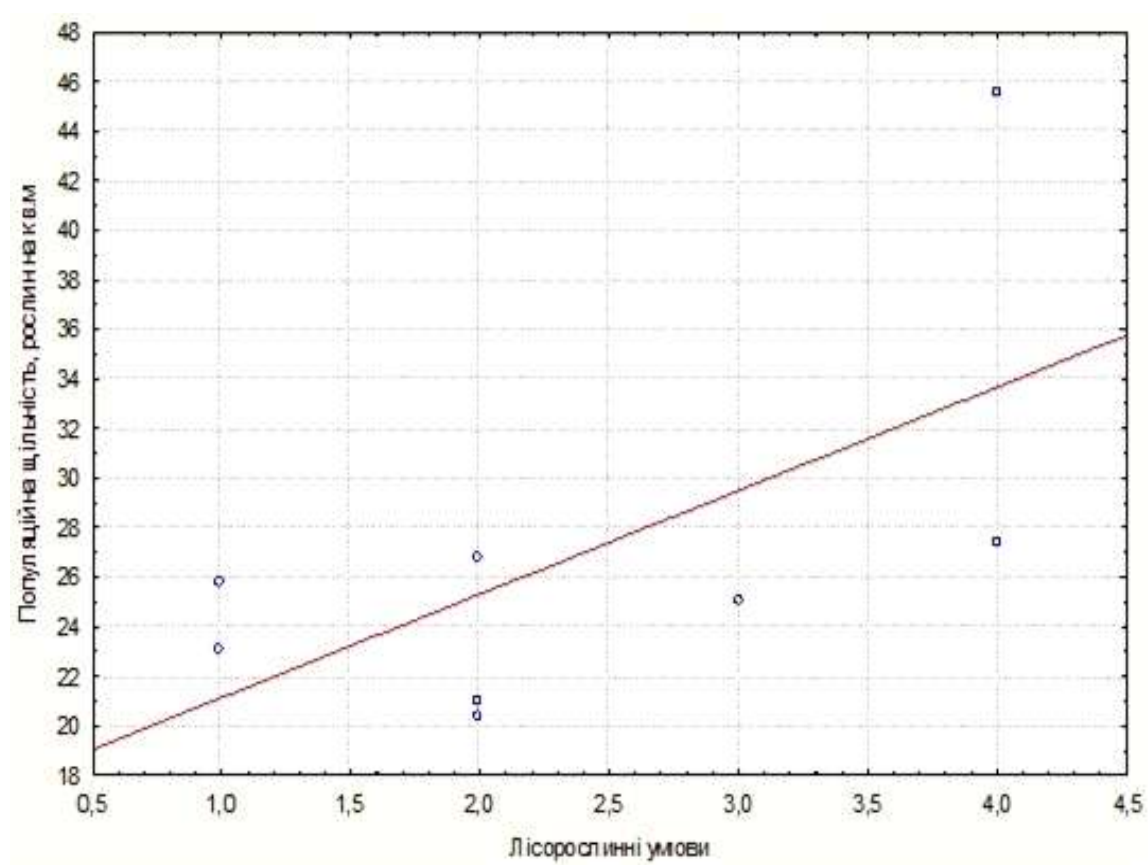

Рис. 1. Популяиійна щільність Convallaria majalis у різних лісорослинних умовах (1 - в умовах звичайнососнових лісів; 2 - звичайнодубових лісів; 3- звичайнодубово-гостролистокленових лісів; 4 звичайнодубово-дрібнолистянолипових лісів)

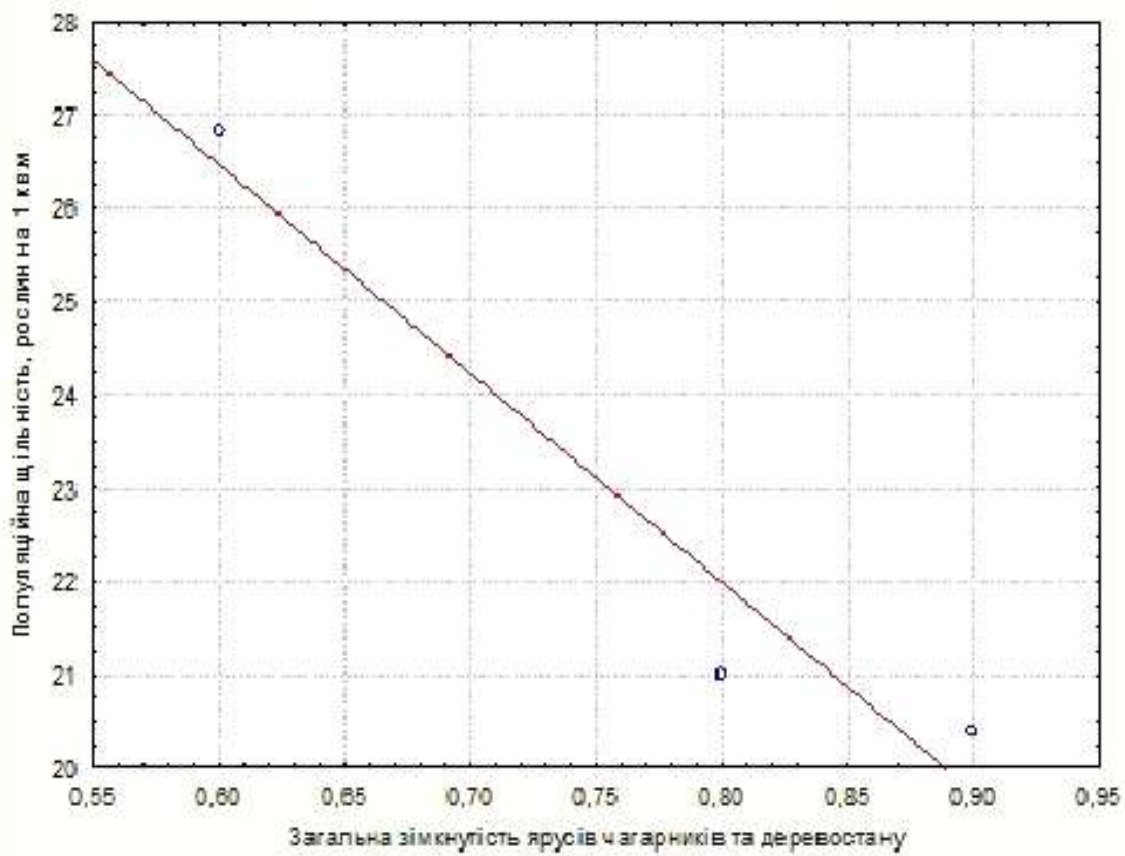

Рис. 2. Зміна популяиійної щільності Convallaria majalis на градієнті загальної зімкнутості ярусів чагарників та деревостану (на прикладі угруповань звичайнодубових лісів)

Відповідно, був проведений аналіз зміни величин популяційної щільності C. majalis на тлі зростання їх популяцій у різних лісорослинних умовах: звичайнососнових лісів (формація Pineta sylvestris, субформація Pineeta sylvestris); 2 - звичайнодубових лісів (формація - Querceta roboris, субформація Querceeta roboris); 3 - звичайнодубово-гостролистокленових лісів (формація - Acereta platanoiditis, субформація Querceto (roboris)-Acereta platanoiditis); 4 - звичайнодубово-дрібнолистянолипових лісів (формація - Tilieta cordatae, субформація Querceto (roboris)-Tilieta cordatae). Встановлено, що всі досліджувані популяції C. majalis відрізняються не лише за показниками популяційної щільності, а й за розміром, які досить часто досягають одного гектара i навіть більше. Найменші значення площі попу- 
Науковий вісник Східноєвропейського національного університету імені Лесі Українки. Серія: Біологічні науки, 2020, 1 (389)

ляційного поля у C. majalis зареєстровані в популяції з угруповання Quercetum (roboris) coryloso (avellanae)-роosum (nemoralis). Тоді як найбільші величини площі у C. majalis припадають на популяцію з угруповання Querceto (roboris)-Tilietum (cordatae) urticosum (dioicae).

\section{ВИСНОВКИ}

Отже, в досліджуваних популяціях C. majalis у показниках площі популяційного поля та популяційної щільності проявилася низка специфічних ознак. Зокрема, за показниками щільності досліджувані популяції розподілилися за трьома групами: 1) популяції, у яких середні значення ознаки варіюють від 20 до 25 рослин $/ \mathrm{M}^{2}$ (популяції 3 угруповань Pinetum (sylvestris) sorboso (aucuparii)-elytrigiosum (repentis), Quercetum (roboris) coryloso (avellanae)-fragariosum (vescae), Quercetum (roboris) coryloso (avellanae)-poosum (nemoralis)); 2) популяції, у яких середні значення ознаки варіюють від 25 до 30 рослин $/ \mathrm{m}^{2}$ (популяції 3 угруповань Pinetum (sylvestris) coryloso (avellanae)-urticosum (dioicae), Querceto (roboris) poosum (nemoralis); Querceto (roboris)-Aceretum (platanoiditis) elytrigietosum (repentis), Querceto (robo-ris)-Tilietum (cordatae) urticosum (dioicae)); 3) у яких середні значення ознаки перевищують 30 рослин $/ \mathrm{M}^{2}$ (популяції 3 угруповання Querceto (roboris)-Tilieto (cordatae) convallariosum (majalis)).

Окрім того, в кожної 3 досліджуваних популяцій значення популяційної щільності закономірно змінюються за місцезростаннями. У досліджуваних об'єктів встановлена залежність величин популяційної щільності від належності фітоценозу до певного типу рослинності, видового складу угруповання, рясності видів, що його формують, від ступеня родючості грунту та рівня освітленості. 3 урахуванням показників популяційної щільності та площі популяційного поля як перспективні осередки регламентованої заготівлі лікарської сировини цього виду можуть розглядатися популяції угруповань Querceto (roboris)-Tilieto (cordatae) convallariosum (majalis), Querceto (roboris)-Tilietum (cordatae) urticosum (dioicae).

\section{ЛITEPАТУРА}

1. Мінарченко, В. М.; Тимченко, І. А. Атлас лікарських рослин Украӥни (хронологія, ресурси та охорона); Фітосоціоцентр: Київ, 2002; 172 с.
2. Лихочвор, В. В.; Борисюк, В. С.; Дубковецький, С. В. Лікарські рослини; Українські технології: Львів, 2003; с 265.

3. Кисличенко, В. С., Ленчик, Л. В., Новосел, О. М., Кузнєцова, В. Ю. Ресурсознавство лікарських рослин. Посібник для студентів спеціальності «Фармація»; НФаУ: Харків, 2015; 136 с.

4. Мулярчук, С. О. Соснові ліси Сумського Полісся. Укр. ботан. журн.; 1970, 3, с 726-730.

5. Барбарич, А. І. Флора і рослинність Полісся Української РСР. Нариси про природу $i$ сільське господарство Українського Полісся; Київський університет: Київ, 1955; с 269-319.

6. Вакал, А. П. Рідкісні та зникаючі види рослин басейну р. Івотки. Екологічні дослідження річкових басейнів Лівобережної Украӥни; СумДПУ імені А. С. Макаренка: Суми, 2002; с 149-154.

7. Чорноус, О.П. Флористичні знахідки на території Шосткинського геоботанічного району (Сумська область). Укр. ботан. журн.; 2005, 3, c 360-363.

8. Чорноус, О.П. Лісова рослинність Шосткинського геоботанічного району (Сумська область). Укр. ботан. журн.; 2006, 3, с 401-409.

9. Андріснко, Т.Л. Рослинний світ проектованого Деснянсько-Старогутського національного парку. Актуальні проблеми створення Деснянсько-Старогутського національного природного парку та иляхи їх вирішення; Київ, 1998; с 62-70.

10. Скляр, В. Г. Розбудова структурних елементів екомережі Поліської частини Сумської області: актуальні питання та практичні підходи. Экосистемы, их оптимизация и охрана; 2013, 8, c 173-182.

11.Ивашин, Ю.Д. Лекарственные растения Украины; У рожай: Киев, 1971; с 352.

12. Рябчук, В. П., Переходько, О. М. Конвалія звичайна (Convallaria majalis L.) в умовах Заходу України. Науковий вісник УкрДЛТУ; 2004, 14.1, c 8-12.

13. Кропотова, И. И. Некоторые данные по экологии и биологической активности ландыша майского (Convallaria majalis L.). Вестник МГУ; 1964, 2, с 73-79.

14. Переходько, О. М. Залежність морфометричних параметрів конвалії звичайної (Convallaria majalis L.) від лісівничо-таксаційних показників лісорослинних умов. Науковий вісник УкрДЛТУ; 2005, 15.3, с 60-63.

15. Кацовец, Е. В. Экологофитоценотические особенности ландыша майского в степном Заволжье (на примере Красносамарского лесного массива). Автореферат дисс. канд. биол. наук. Самара, 2011; c 20 .

16. Мінарченко, В. М. Лікарські судинні рослини України (медичне та ресурсне значення); Фітосоціоцентр: Київ, 2005; с 324 . 